\title{
RELIGION, LEADERSHIP AND STRUGGLE FOR POWER IN NIGERIA: A CASE STUDY OF THE 2011 PRESIDENTIAL ELECTION IN NIGERIA
}

\section{Danoye Oguntola-Laguda}

Lagos State University

danoyeoguntola@yahoo.com

\section{ABSTRACT}

The crisis of leadership today in Nigeria provides a formidable challenge to political and other social scientists. Between 1999 and 2015 several elections have been held with many leaders elected and sworn into office; with interactions between religion and politics the ongoing subject of academic analysis (Abubakar 1984; Igboin 2012; Kukah 1998; Oguntola-Laguda 2008; and so forth). Political office holders often drew on religious ideas, practices and symbols as a tool of negotiation with the electorate during political campaigns. As a result, candidates were often selected based on their religious rhetoric and affiliations. Thus the debate about Muslim/Muslim or Muslim/Christian tickets emerged as a key issue in the elections. Religious leaders are often political actors in the elections. There were several media allegations that some religious leaders were complicit in compromising and corrupting the electoral process. Many prophetic statements preceded the 2011 elections. For example, the prominent Pentecostal leader and presidential candidate, Pastor Kris Okotie, the general overseer of Household of God Church in Lagos, prophesied (unsuccessfully) that he would be sworn in as president after the election.

In this paper we will examine how political leaders managed (or manipulated) their religious claims and allegiances in the pre- and post-election periods in 2011, against the backdrop of a religiously pluralistic setting such as Nigeria, and the resultant contradictions. Particular attention will be paid to the concepts of power and authority, as these are central to both worlds of religion and politics. Additionally, I will discuss the varying differentiations of the religious and political

\section{UNISA $\cong$}


domains in the political process, campaign speeches, sermons and prophecies, perceptions of individual politicians, as well as media and popular opinion.

Key words: Nigeria; religion; leadership; politics; conflict; power; presidential elections.

\section{INTRODUCTION}

The crisis of leadership today in Nigeria is borne out of the seemingly uncaring and irresponsive disposition of people in power to the reality of the impoverished state of their followers. This position is reinforced by the non-availability of basic infrastructures, social services and an enabling environment that will make the followers emancipate from this impoverished state. Apart from the fact that most of the political office holders often reneged on their electoral campaign promises vis-àvis their party manifestoes (which often are mass oriented), they relied on religion as a tool of negotiation with the electorate during electoral campaigns. However, they put religion aside immediately after they had secured power to administer the state. The point here is that political leaders often relied on religion to acquire political power, only to abandon its doctrines and ethical dictates after electoral victory. Thus, religion becomes a means to political ends.

In Nigeria people who aspire to be leaders seem to be religious only at the point of trying to mobilise the electorate and while canvassing the unsuspecting masses for votes. After the election(s), and in the process of the struggle for power, the teachings, ethics and doctrines of religion are neglected. It is my conviction that if indeed guided by the principles of their religion(s), Nigerian political leaders would be considerate and see religious ethics as a matrix upon which leadership could be built.

The 2011 general election in Nigeria is a veritable example of process, purpose and methods often adopted by politicians seeking political power (struggle for power). In the build-up to the 2011 presidential election in Nigeria, there were cases of political assassination, mudslinging and calumny among the political echelons. During elections proper, a lot of fraudulent actions were reported by local and international observer groups. ${ }^{1}$ Even when the election results were declared, the Nigerian polity was brought to crisis point with calls for violence by General Muhammad Buhari. Buhari was one of the electoral losers who called for mass action against the ruling party at the expense of the legal and judicial process already put in place by the Electoral Acts.

This paper examines the conflict in the position of politicians seeking leadership positions in Nigeria against the backdrop of the teachings, ethics and doctrines of

1 Many foreign and local observer groups were invited by the Independent National Electoral Commission (INEC) to monitor the 2003 electoral process in Nigeria. 
their religion(s), which dictate that power, leadership and authority belong to the creator of heaven and earth, God. I seek to explain this conflict with an appraisal of the 2011 presidential election and its aftermath in Nigeria. A conceptual analysis of the responsibilities of leadership as well as the religious dictates in this regard will be carried out. I attempt to show that even though Nigerian leaders claim to be religious in pre-election situations, their reaction to election results (especially when they lose elections) and their struggle for power, bear evidence to the contrary.

\section{RELIGION, LEADERSHIP AND POWER}

The term religion can be broadly interpreted from functional and substantive perspectives. The former explains the mystery of religion while the latter is a clear pointer to the necessity of religion in human socio-cultural development. My concern in this essay is mainly on the functionality of religion. In this regard, Milton Yinger explains religion as a system of beliefs and practices through which a group of people struggles with problems of human existence. ${ }^{2}$ Emile Durkheim claims that religion is a phenomenon that unites people into a moral community, which must adhere to its ethics. ${ }^{3}$ Karl Marx, however, argues that religion is a tool in the hand of the elite at oppressing the masses. To him, religion is often used to suppress the thinking of the masses and bring them to submission. He writes:

Religion is the sigh of the oppressed creatures, the heart of a heartless world and the soul of soulless condition. It is the opium of the people. ${ }^{4}$

The submissions of the three scholars mentioned above suggest that religion is a social instrument with capacity to engender socio-economic development in a society, depending on its usage. To Yinger and Durkheim, religion could lead to positive interactions and social identifications through observance of and reliance on its ethical codes. On the contrary, Marx's arguments suggest that religion is only a 'means to an end' and which is often retrogressive as it reduces or eliminates the development of individuals and society. To the Marxists, religion is an attempt to pacify the oppressed masses.

From a moralist point of view, Immanuel Kant explains religion as:

The belief, which sets what is essential in all adoration of God in human morality... Religion is the law in us, in so far as it obtains emphasis from lawgiver and judge over us. It is a morality directed to the recognition of God. ${ }^{5}$

2 G. Van der Leew, Sacred and Profane Beauty: The Holy in Art. (London: Weiden Feld \& Nicholson), 1963, p. 102.

3 G. Aderibigbe, 'Definition of Religion,' in G. Aderibigbe and DejiAiyegboyin, Religion. Study and Practice. (Ijebu Ode: Alamsek Press), 1997, p. 3.

4 B. Pascal, Pensées, Translated by W.F Trother. (New York: Random House), 1941, p. 22.

5 Aderibigbe, p. 6. 
The submission of Kant suggests that religion is all about the recognition of the supreme law giver (God) and obedience it engendered from those who express a belief in Him. Although Kant has been accused of equating religion with morality, the strength of his explanation lies in the interaction it implies between the moral law giver (God) and man, who is the recipient of the law. Man is expected to obey all the laws in order to be adjudged moral with some reward.

From the definitions examined above, we observe that religion has serious social dimensions and implications. These effects can only be felt positively or negatively depending on how man reacts and accepts the precepts, doctrines, principles and laws that form the bedrock of religion.

Leadership could be defined as follows:

Being a leader or the ability to be a leader, to show the qualities of leadership necessary in a team. ${ }^{6}$

Acknowledging the multidisciplinary approach to leadership, J.M Burns defines leadership as:

A structure of action that engages a person to varying degrees, throughout the levels and among the interstices of societal units. ${ }^{7}$

The definition of Burns suggests that leadership cuts across all strata of society with the attempt to make a person lead others as agents. That is, leaders are supposed to be agents of their followers. Describing the attributes of a leader, Julius Nyerere explained that:

When you are selected to lead your fellowmen, it does not mean that you know everything better than the followers. It does not mean that you are more intelligent than the followers. ${ }^{8}$

The submission of Nyerere points to the fact that leaders are selected (or elected) and the position does not make knowledge exclusive to them. Therefore, the effectiveness of a leader could be measured by the social change that emerges from their interaction with the followers by intent and by the satisfaction of their needs and expectations. It shows that leadership and followership have a mutual relationship based on needs, aspiration and values. ${ }^{9}$

It further shows that leadership transcends the struggle for and the holding of power, it is more about the use of such a position to the benefit of the followership. Also, in the process of selection or election, the followers are capable of 'choice' among available aspirants and their programmes.

6 A.S. Homby, Oxford Advanced Learner's Dictionary of Current English. (New York: Oxford University Press), 1995 7th edition, p. 669.

7 J.M. Burns, Leadership.(New York: Harper Torchbooks), 1978, p. 120.

8 J. Nyerere, 'Leaders must not be masters' in E.C. Eze (ed.), African Philosophy: An Anthology (Maiden: Blackwell, 1998), p. 79.

9 Burns, p. 4. 
Three types of leadership have often been identified by scholars; ${ }^{10}$ these are transactional, transforming and moral. Transactional leadership gives opportunities for leaders to approach the followers to exchange one thing for another. For example, jobs for votes, subsidies from corporate bodies for campaign contributions, food items for votes, etc. Transforming leadership recognises the needs and demands of followers and seeks to satisfy them through stimulation. The moral leader seeks to promote and produce social change through the enforcement of moral codes on the followers. Although many political actors in Nigeria often laid claim to the first two models of leadership, the situation in the country points to the contrary. The model of leadership is transactional to my mind. This explains why political actors appropriate religious images, symbols and ritual spaces to negotiate for votes during their campaign.

From the above, we can submit that leadership is a concept which seeks to examine the process and means for the acquisition of power, to lead and mobilise the followership in all strata of society, perhaps to engender socio-cultural development and political actions.

Power, and the struggle towards achieving it, has in recent times become intense globally. This is primarily because of the values attached to it and the uses to which it is often put. Millions of people are reported to have been killed, maimed or assassinated by those struggling to acquire power. ${ }^{11}$ Bertrand Russell defines power as 'the fundamental concept in social science, in the same sense in which energy is a fundamental concept in physics' ${ }^{12}$ Max Weber also explains power and the struggle inherent to it as:

The probability that one actor within a social relationship will be in a position to carry out his own will despite resistance, regardless of the basis on which this probability rests. ${ }^{13}$

From the above, Russell and Weber suggest that power is a necessity in society. However, the struggle for power has made imperative the interaction between leadership and followership, making it a part of the system of 'social causation'. Burns explains power as follows:

Power is a process in which power holders, possessing certain motives and goals, have the capacity to secure changes in the behaviour of a respondent [human or animal and in the environment] by utilizing resources to their power base including factors of skill, relative to the target of their power wielding and necessary to secure such changes. ${ }^{14}$

10 These scholars include James Bums, Ronald A. Heifetz, and Marty Linsky, among others.

11 The recent struggle for power in Liberia, Cote d'Ivoire, Iraq, Sao Tome and Principe are veritable examples among others

12 B. Russell, Power: A New Social Analysis.(New York: Norton), 1938, p. 1.

13 M. Weber, The Theory of Social and Economic Organisation, quoted by R.A Dahl 'Power' in International Encyclopaedia of the Social Sciences. (New York: Free Press and Macmillan), 1968, Vol. 12, p. 406.

14 Burns, p. 13. 
The motive of power holders and recipients is the basis of Burns's position. Thus, the interaction between the power seeker (leadership) and power givers (followership) is a necessary factor for the benefits of power to be actualised.

The struggle for power has assumed fatal and fraudulent dimensions universally. This is often based on the motive of the power seekers. These include wielding power to pursue recognition, prestige, glory, social control, economic wherewithal, novelty and excitement, as well as exhibiting assumed skills, knowledge and the ability to stimulate their own capacities and master the environment.

The interaction among the three concepts (religion, leadership, power) examined in this section will enhance the development of society. That is, if aspirants to leadership positions take seriously the moral injunctions of their religion, the struggle for power will not be as intense as we now witness in the world. Moreover, since some religions (especially African Traditional Religion, Islam and Christianity that are dominant in Nigeria) preach that power belongs to the Numinous and that $\mathrm{He}$ chooses whom He desires to wield it and lead the society, there should not be such an intense struggle for power as witnessed in Nigeria, especially in the pre-election and aftermath of the 2011 presidential election.

\section{RELIGION AND THE STRUGGLE FOR POWER IN NIGERIA}

In spite of the influence of Western culture, globalisation and Western education, the general Nigerian populace still holds religion in high esteem. This 'institution' has affected all strata of their lives. It is not uncommon today to see early morning devotion in private and public institutions. The same could be said about political meetings, campaigns and congresses. However, this loyalty seems to be peripheral, as most of those who claim commitment to religious callings, often abandon it at the point when it conflicts with their secular interests. The struggle for power in leadership positions is not an exception in this regard. The general dictum in Nigeria is that all citizens are religious in all their undertakings. However, other interests (including political aspirations) of individuals and groups have often relegated religion's beliefs and influences to the background in secular matters, making the theoretical postulations of Yinger and Durkheim on the positive values of religion to wane when applied to the Nigerians' quest for power in political situations.

The three religions dominant in Nigeria today hold the view that power and the use of it rest with God who will dispense it according to His wish. In Christianity, God is presented as the author and origin of power as expressed in leadership. Thus in the book of Isaiah God is reported to have said:

I have given him for a witness to the people, a leader and commander to the people. (Is. 55:4)

The quotation above suggests that no matter what process is adopted in the struggle for leadership and control of power, Christians should know that God is the one that 
chooses who is to be a leader. Furthermore, leaders are admonished not to lie to their followers, as this will lead to damnation. This position is exemplified in Matthew as follows:

They are the blind leader of the blind. And if the blind lead the blind both shall fall into the ditch. (Matt. 15:14)

It is perhaps based on the above that criteria for leaders were set out as follows:

A bishop ${ }^{15}$ must be the husband of one wife, vigilant, sober, of good behaviour, given to hospitality, apt to teach. Not given to wine, no striker, greedy of filthy lucre but patient, not a brawler, covetous. One that rules well his own house, having his children in subjection with all gravity, for if a man know not how to rule his own house, how shall he take care of the church of God? He should not be a novice. (1 Tim 3:1-6)

From the above criteria, it is obvious that leadership position in Christianity is not open to all and sundry. Morality and values attached to it must be fulfilled by anybody who aspires to lead the people. However, where there are many qualified persons for a leadership position, the people should rely on God for a choice through His agents. In the early church, leadership appointments were made by the Apostles of Jesus Christ (Act 14:23). Also, a leader is expected to guard the truth of the gospel from pervasion and administer the church as the head (Act 20:28; Heb 13:17).

In Islam, every Muslim is seen to be holding a position of authority. Therefore he has the potential to be a leader; since everybody will be held responsible to account for the post he held. This implies that there could be a struggle for power among Muslims. However, leadership is seen as trust, which nobody can achieve unless given by Allah. The Qur'an reports thus:

O Allah, Lord of power and rule, Thou giveth power to whom Thou pleases, and Thou strippest off power from whom Thou pleases. Thou endues with honour that Thou phase, and Thou bringest low whom Thou pleases, in Thy hand is all Good. Verily, over all things Thou hast power. (Q3: 26)

The implication of the verse quoted is that in the process of struggling for power Muslims must remember that Allah is the custodian of power and he dispenses it according to his will. Historically, political leadership in Islam is placed on the religious leaders who are referred to as Khalifah. During the lifetime of Prophet Muhammad, the civil and religious controls were placed on him as the commander of the faithful. A leader is expected to maintain peace on earth among the creatures of Allah by his commandments and injunctions. According to M.M Ali, a leader (Khalifah) is 'one who judges among, or rules the creatures of Allah by his command ${ }^{16}$ and whoever obey these leaders will be rewarded (Q 33:71).

15 A bishop in the early church history is the spiritual and administrative leader of the church.

16 M.M. Ali, The Holy Qur'an: Arabic Text, Translation and Commentary.(Great Britain: A.A. Versage, 1951), p. 17. 
The followers are also enjoined to follow the precepts of Islam as given by Allah and His appointed leaders. This is emphasised in the Qur' an thus:

O ye who believe, obey Allah, and obey his messengers and those charged with authority among you. If ye differ in anything among yourselves, refer it to Allah and His messengers [leaders] if ye do believe in Allah and the last day, that is best and most suitable for final determination. (Q4: 59)

The principle behind this verse is that consultation is vital in the interaction between the leadership and the followership for socio-cultural, economic development and political stability of society (Q3: 159). Intact victory is assured for those who obey Allah. Commenting on the issue of leadership, followership and trust in Islam, Ali, submits as follows:

Trusting in Allah does not imply inaction. Everything necessary is to be done, a course of action must be determined in the proper manner and in pursuing that course trust must be placed in Allah. This implies that a man should do his utmost and then leave the consequences to Allah. That is he must be resigned to what follows. ${ }^{17}$

From the Islamic perspective, therefore, leadership is a position of trust, which is endowed on anybody according to the will of Allah. The struggle for power should be based on faith in Allah and trust in the principle that the final decision rests with him. Furthermore, the followers are expected to give allegiance to their leaders who are representative of Allah.

In African traditional religion, the Supreme Being is conceived as the origin and source of all powers. 'He has full prerogative and exercises it over all. His will is absolute. ${ }^{18}$ Therefore, leadership is a concept that is derived from the source of all beings. Leaders derived their own authority from him. They are expected to discharge civil as well as religious functions ${ }^{19}$ according to the will of the Numinous. Taking the Yoruba ${ }^{20}$ example, the political leadership is monarchical and selection and appointment are based on the directives of Olodumare through the Ifa oracle. ${ }^{21}$ It is allowed that princes engage in power struggle, but once one among them is chosen as the king, it is expected that all others should give allegiance and support to him as Alase, ekejiorisa (the wielder vice regent of the divinities).

However, in the process of selecting the chiefs and other lesser political office holders, Fadipe submits on the process in Oyo Empire as follows:

17 Ibid, p. 316.

18 E.B. Idowu, Olodumare: God in Yoruba Belief. (Lagos: Longman 1996), Enlarged Edition, p. 37.

19 N.A. Fadipe, The Sociology of the Yoruba. (Ibadan: University Press, 1970), p. 202.

20 The Yoruba are one of the three dominant tribes in Nigeria. They occupy the seven south-western states in the country.

21 Ibid, p. 205. 
The form, which the control of Alaafin took in the election of kings [head of vassal kingdoms] lies in his decision in favour of one or other of rival claimants who courted the king's favour with presents. ${ }^{22}$

The implication of Fadipe's submission is that such selections are not based on merit.

The struggle for power and leadership position is premised on the belief of Africans in the will of the Supreme Being. The Yoruba will say:

A dun'un se bi ohuntiOlodumare se, A soroo-se bi ohuntiOlorunkolowosi, [Easy to do as that which Olodumare approves. Difficult to do as that which Olorun disapproved].

Therefore, if one struggles for leadership position and fails to secure it, he accepts his fate as the will of his creator, believing that power belongs to God.

From our discussion so far, we observe that the three dominant religions in Nigeria share the belief that leadership position is bestowed on people according to the will of the Supreme Being who is seen as the creator, designer and sustainer of human destiny. It is interesting, therefore, to note that those who struggle for leadership position in the country, in spite of their claim to be religious, are not faithful to the doctrines, teachings and precepts of their religions. The aftermath of the 2011 presidential election in Nigeria has proved that politicians only use religion as a vehicle in achieving their aims; they often resorted to extra-judicial means in seeking redress when they failed in their quest for power and leadership positions. Some of these means are against the teachings of their religions. Therefore, we can say that people appropriate religion as a tool for political power struggles, thereby becoming Machiavellian in the process. ${ }^{23}$

During the presidential election campaigns leading up to the 2011 presidential election, political parties used religious images, symbols and icons as some of the political tools of negotiation with the electorate. The candidates of the People Democratic Party (PDP) and Congress for Progressive Change (CPC) visited religious ritual spaces to canvass for votes. It was reported in the media that the PDP candidate visited and participated in the worship services of prominent Pentecostal churches in the country. For example, he was at the Redeemed Christian Church of God (RCCG), The Lord Chosen Church and the Covenant Church. The three churches were the leading Pentecostal churches in Nigeria at that time. The candidate of CPC also visited churches. Islamic ritual spaces were also visited by both leading candidates. Furthermore, leading contestants in the election selected their running mates based on religious affiliation. General Muhammad Buhari used Tunde Bakare, a prominent Pentecostal preacher in the country as his running mate.

22 Idowu, p. 37.

23 Niccolo Machiavelli, a great writer of the Renaissance era, advised princes (rulers) to protect their own interest and that of the state above others. To him, they should pay lip service to religion and its precepts. See M.D Wilson et al., Philosophy: An Introduction.(New York: Appleton Century Crafts, 1972), p. 626. 
Goodluck Jonathan adopted the incumbent Vice President, Sambo, a Muslim, as his running mate. There were also incidents of sermons and visions of contestants in the election that informed their congregations that they were ordained to become the president after the election. Pentecostal leader and presidential candidate (of the Justice Party), Pastor Kris Okotie, the general overseer of Household of God Church in Lagos, prophesied (unsuccessfully) that he would be sworn in as president after the election. The implication is that religious leaders are also seen as political actors in the Nigerian political terrain. The demographic implications of the results of the election suggest that Nigerians voted not only on ethnic and tribal sentiment, but also on religious sentiment. The predominant Christian South East voted for Goodluck Jonathan, while the North West (a Muslim dominated area) voted for Buhari, a Muslim.

\section{THE 2011 PRESIDENTIAL ELECTION IN NIGERIA AND ITS AFTERMATH}

The presidential election was held in Nigeria on Saturday 16 April 2011, under the auspices of the Independent National Electoral Commission (INEC). Many observer groups were invited to bring credibility into the election and afford independent opinions and observations on the conduct of the election. Out of the 63 registered political parties only 21 fielded candidates for the presidential election. It is important to note that only one female candidate - Ebiti Ndok (of UNDP) contested the presidential election. The build-up to the election witnessed cross carpeting from candidates who lost out at parties' primaries and later emerged as candidates of other parties. ${ }^{24}$ Those who moved to other parties alleged fraud and malpractices at the parties' presidential primaries. This is a clear demonstration of the selfish interest of the Nigerian political class to abandon their religious dictates (that power belongs to God and He gives such power to whoever He desires) when they lose any election. There was the debate whether a southerner (Goodluck Jonathan) should emerge as the president of Nigeria after the demise of the sitting president Umar Ya'dua, a northerner. This perhaps explains the violence that greeted the announcement of Jonathan as the winner of the 2011 presidential election. ${ }^{25}$ Muhammad Buhari (a northerner and a Muslim), the presidential candidate of the Congress for Progressive Change (CPC) rejected the results and called on Nigerians to reject the results and go into mass actions against the government. He was quoted to have said:

24 Jim Nwobodo, Ike Nwachukwu, Kris Okotie among others changed parties. The first two, moved from the People Democratic Party (PDP) to the United Nigerian People Party (UNPP) and the National Democratic Party (NDP) respectively. The last crossed from the NDP to the Justice Party (JP).

25 www.inecnigeria.org/results/2011. 
Any government formed on the basis of the April 16th (presidential poll) would be illegitimate. ${ }^{26}$

He enjoined the international community not to recognise the government that would be established based on the results of the elections. He called on Nigerians to engage in mass action against the government. In this regard many lives were lost (800 was reported in the media) during the post-election violence, especially in Kaduna. ${ }^{27}$

This is contrary to the dictates of Islam, his religion as discussed above. In Islam, Muslims are enjoined to leave all such matters in the struggle for power to Allah, having done the needful during the struggle for power. This call for mass action against the sitting government led to killings, arson and civil disobedience in the northern parts of the country. This further demonstrates that ethnic and tribal sentiments were some of the factors often deployed by the Nigerian political class in the struggle for power and leadership positions, often at the expense of religious beliefs and affiliations.

It is also noteworthy that all the candidates for the election laid claims to one form of religion or the other. ${ }^{28}$ In fact some of these candidates were leaders in their ritual spaces. ${ }^{29}$ Interestingly, these are among those involved in cross carpeting after the presidential election primaries of political parties. Furthermore, all the candidates adopted religion as a tool of negotiation during the election campaigns as mentioned above.

Generally, the election was conducted in a peaceful atmosphere with some reports of irregularities in some parts of the country. There was a good voter turnout for the election (53.7\%). There were, however, pockets of violence in some parts of the country, especially in the south-eastern region leading up to the election. Three days after the election, the INEC announced the results ${ }^{30}$ of the election and the incumbent Goodluck Ebele Jonathan was declared the winner. ${ }^{31}$ The European Union Observer Group, National Democratic Institute (NDI), International Republican Institute (IRI) (from the United States of America), the Catholic Church Election Monitoring Group, Transition Monitoring Group (TMG), Commonwealth Observer Group, among others, monitored the elections across the country. The reports of

26 The Sun Newspaper, Thursday April 20th 2011, p.4.

27 Awopeju, Ayo,2011 Presidential Election and the Political Participation in Nigeria, Canada Social Science, Vol. 8(2), March 2012.

28 Out of the 19 candidates, three are Muslims while 16 are Christians. The Sun Newspaper, Thursday April 20th 2011, p.4.

29 Chris Okotie and A. Agoro are leaders and founders of their church movements.

30 The Punch Newspaper, Thursday, May 15, 2011, p. 2. It was reported that the incumbent President Goodluck Jonathan won the presidential election scoring $61.94 \%$ of the total votes cast in 766 of the country's 774 local government area. He polled 24,456,140 votes out of 39,078,558 valid votes cast. His closest opponent, Muhammad Buhari of (ANPP) polled 12,710,290 (32.03\%). Other contestants shared the remaining 1,912,128 votes among them.

31 Ibid, p. 2. 
these groups were confusing, conflicting and contradictory. The European Union Observer Group submitted on the elections as follows:

The April elections were marred with irregularities and fraud in no fewer than thirteen states...minimum standard for democratic elections were not met. ${ }^{32}$

However, the European Union, which is represented by the Observer Group, welcomed the results of the presidential election with the claim that the election was conducted in a peaceful atmosphere. This position was embedded in the following words:

The European Union welcomes the fact that the presidential, parliamentary and gubernatorial elections in Nigeria, were conducted peacefully in most parts of the country and represent an important step for the democratic process in Nigeria. ${ }^{33}$

The National Democratic Institute and International Republican Institute alleged electoral fraud and malpractices but posited that these were not enough reason to invalidate the conduct and results of the elections. The opinion of the Commonwealth Observer Group was not different from the submissions of the Transition Monitoring Group and the Catholic Church Election Monitoring Team, who among other local monitors, reported many incidents of electoral fraud and malpractices; but still believed in the sanctity of the elections and the results. The United States Department of State said 'the election was successful and a substantial improvement over the 2007 presidential election, but noted that vote rigging and fraud also took place'. There were also allegations of underage voting and snatching of ballot boxes.

It should be stated, however, that unlike the 2003 presidential election, where mass action was called for by joint efforts of the defeated political parties, it was only the CPC that mobilised for such actions. These actions heated the polity and brought tension to the minds of many Nigerians; most of whom stayed indoors on Thursday, May 29, 2011, when Goodluck Jonathan was sworn in as president of the Federal Republic of Nigeria, for fear of chaos and violence that could surface during the inaugural ceremony.

From the reactions of defeated candidates in the Nigerian 2011 presidential election, it will seem that these are not religious people. As we observed earlier, all religions in Nigeria teach and preach that power and leadership positions are the prerogative of the Supreme Being (God) and He gives it to whom he pleases. The question therefore is, are the candidates ignorant of the teachings of their religions on leadership and power acquisition? SuleTolani, a politician, argues that it is very difficult for a politician to be religious. He explained that most politicians pay lipservice to religion and adopt it as a means to an end. He submitted further:

32 Ibid, p. 4.

33 The Punch Newspaper, April 24, 2011, p. 2. 
Most politicians [in Nigeria] are investors. They invest their time and resources in the election process; thus, it becomes difficult to accept defeat in the face of cost and lost investment. Further most of these politicians are representatives of groups, parties, caucuses and even when they want to dump the struggle they are often urged on by these groups. ${ }^{34}$

Fiso Oyeniyi, a pastor in the Christ Apostolic Church (CAC), agreed with the opinion of Tolani. ${ }^{35}$ He however, believed that it is the lack of fear and respect for God and His commandments that often creates this situation. To him, if politicians accept the precepts and doctrines of their religion, then the quest for leadership position will not be 'a do-or-die affair'. The president of the Christian Association of Nigeria (CAN) also admonished defeated candidates to accept the result of the election as the wish of God.

The Imam of Lagos State University Muslim Community, Amidu Sanni, in one of his sermons, suggested that Allah is the origin and controller of power and he gives it to whom he wishes. Although, he believed that irresponsible leadership had been the bane of Nigeria as a country, he submitted that Allah would not be happy with any leader who is not faithful to the electorates. He therefore enjoined the followership to be vigilant and pray for Allah's guidance in choosing leaders for our country. ${ }^{36}$ Mustapha Ade-Bello agreed with the position of Sanni, but insisted that everybody in Islam is a leader, but such must be ready to give account of his actions and deeds before Allah. Asked, to comment on the reactions of defeated candidates to presidential election result, he said:

Even though, Allah gives leadership to whom He pleases, Islam is against injustice or cheating. Thus seeking redress and justice is not against Islamic principles. ${ }^{37}$

The submission of Imam Sanni here is not to support violence. It is rather a call on the politicians to use peaceful and legal means in the quest to seek redress and justice.

On the whole, it is obvious that all religions in Nigeria preach against violence and encourage peaceful and harmonious co-existence, therefore the call for 'mass action' by some defeated candidates in the April 16 2011 presidential election, to my mind could be classified as unreligious and tribal. At the time of the election the Nigerian polity was already heated due to the demise of the sitting president Umar Ya Adua, and the clamour that a person from his geopolitical zone in the north-west should replace him to further the leadership interests of that part of the country.

34 Oral interview with Mr Sule Tolani, a lawyer and politician. aged 51 at his residence No. 6 Olayemi Street, Iba Town, Ojo Local Government Area of Lagos State (June 11, 2014).

35 Oral interview with Pastor Fiso Oyeniyi, aged 59 a retired electrical engineer at his resident, No. 4 Oguntokun Street, Ago-Palace Way, Okota (June 10, 2011).

36 Oral interview with Amidu Sanni, Chief Imam, Lagos State University Community Mosque, Ojo, Lagos.

37 Oral interview with Mustapha Ade-Bello, a Muslim, cleric in Agege, a sub-urban area of Lagos. 
The demographic distribution of the results demonstrated the fact that all regions in Nigeria voted massively for the incumbent. It should be noted that the CPC candidate won in the north-west of the country, but by a slim margin. It is a direct indication that even though they claim to be religious, it is only in name and during campaigns. The post-election attitudes of Nigerian politicians as demonstrated in the presidential election of 2011 are a clear manifestation that politicians will dump religions in the refuse bin and embrace profane approaches as a mechanism for problem solving, against the principles of their faith. This was indeed the case with the candidate of $\mathrm{CPC}$ earlier cited above.

\section{CONCLUSION}

From our discussions we observe that leadership and followership need to interact positively to engender socio-cultural and economic development in any society. Also, politics and religion can interact positively in a pluralistic society like Nigeria. This position is also encouraged by the dominant religions in Nigeria, with a caveat that leadership is under the control and will of the Supreme Being who is the designer and sustainer of human destiny and fate on earth. This will suggest that the quest and struggle for leadership positions should be premised on religious teachings and precepts. This will make the process rancour free and bring peace and stability to the polity. However, the Nigerian experience has proved that those who struggle for leadership positions only pay lip-service to their religious callings. Thus, I wish to conclude that even though politicians are supposed to be religious, they prefer to adopt revolutionary means to seek redress in response to election results as demonstrated in the post-election violence, as witnessed in 2011 in the northern parts of Nigeria. If they can abide by the dictates of their religions, then the quest for power will not be lethal; as we had witnessed in Nigeria during the April 2011 presidential election.

\section{LIST OF REFERENCES}

Abubakar, R.D. 'Nortrum for religious tolerance in polity of a multi-religious state: The Nigerian experience.' In Onaiyekan, John (ed), Religion, peace and unity in Nigeria. Ibadan: NASC 1984, p.129.

Aderibigbe, G. 'Definition of Religion,' in G. Aderibigbe and DejiAiyegboyin, Religion. Study and Practice. Ijebu Ode: Alamsek Press, 1997, p. 3.

Ali, M.M. The Holy Qur'an: Arabic Text, Translation and Commentary.Great Britain: A.A. Versage, 1951, p. 17.

Awopeju, A. 2011. Presidential Election and the Political Participation in Nigeria, Canada Social Science, Vol. 8(2), March 2012.

Burns, J.M. Leadership. New York: Harper Torchbooks, 1978, p. 120. 
Fadipe, N.A. The Sociology of the Yoruba. lbadan: University Press, 1970, p. 202.

Homby, A.S. Oxford Advanced Learner's Dictionary of Current English. New York: Oxford University Press, 1995, 7th Edition, p. 669.

Idowu, E.B. Olodumare: God in Yoruba Belief. Lagos: Longman 1996, Enlarged Edition, p. 37.

Igboin, B.O. 'Fundamentalism, security crisis and tolerance in global context: The Nigerian experience', Politics and Religion Journal, Vol. 6(2): 2012 p.113.

Kukah, M. 'Religion and civil society.' In Dukor, M. Philosophy and politics: Discourse on values and power in Africa, Lagos: Obiorah and Ogbiriaka, 1998 p.16.

Nyerere, J. 'Leaders must not be masters' in E.C. Eze (ed.), African Philosophy: An Anthology. Maiden: Blackwell, 1998, p. 79.

Oguntola-Laguda, D. 'Religion and politics in a pluralistic society: The Nigerian experience', Politics and Religion Journal, Vol. 2(2), 2008, Belgrade, p.123-124.

Pascal, B. Pensées, Translated by W.F Trother. New York: Random House, 1941, p. 22.

Russell, B.Power: A New Social Analysis. New York: Norton, 1938, p. 1.

The Sun Newspaper, Thursday April 20 ${ }^{\text {th }}$ 2011, p.4

The Punch Newspaper, Thursday, May 15, 2011, p. 2.

Van der Leew, G. Sacred and Profane Beauty: The Holy in Art. London: Weiden Feld \& Nicholson, 1963, p. 102.

Weber, M. 'The Theory of Social and Economic Organisation,' quoted by R.A Dahl 'Power' in International Encyclopaedia of the Social Sciences. New York: Free Press and Macmillan, 1968, Vol. 12, p. 406.

Wilson, M.D. et al. Philosophy: An Introduction. New York: Appleton Century Crafts, 1972, p. 626.

www.inecnigeria.org/results/2011

\section{Oral interviews}

Oral interview with Pastor Fiso Oyeniyi, aged 59, a retired electrical engineer at his resident, No. 4 Oguntokun Street, Ago-Palace Way, Okota (June 10, 2011).

Oral interview with Mr Sule Tolani, a lawyer and politician, aged 51 at his residence No. 6 Olayemi Street, Iba Town, Ojo, Local government area of Lagos State (June 11, 2014).

Oral interview with Amidu Sanni, Chief Imam, Lagos State University Community Mosque, Ojo, Lagos.

Oral interview with Mustapha Ade-Bello, a Muslim, cleric in Agege, a suburban area of Lagos. 